\title{
Elisabet Arnó-Macià*
}

Theory and History of Architecture and Technical Communication Department

Universitat Politècnica de Catalunya, Spain

Elisabet.arno@upc.edu

\section{Marta Aguilar}

Theory and History of Architecture and Technical Communication Department Universitat Politècnica de Catalunya, Spain

Marta.aguilar@upc.edu

\section{ESP, EMI AND INTERCULTURALITY: HOW INTERNATIONALISED ARE UNIVERSITY CURRICULA IN CATALONIA?}

\section{Abstract}

This study analyses Internationalisation at Home (IaH) courses across a wide range of bachelor's degrees, from humanities to hard sciences, in public universities in Catalonia, as an in-depth analysis of a South European context. IaH courses selected for analysis included courses (i) on international topics, (ii) taught in English and focusing on content (English-medium Instruction, EMI) and (iii) focusing on language, i.e. English for Specific Purposes (ESP). Results point to a high presence of international content courses, especially in humanities and social sciences, followed by EMI courses, although quantitatively scarce and mainly found in engineering. ESP courses are the least present despite their potential to prepare students for EMI. Reasons that may account for this IaH picture are presented. All in all, it seems that current policies leave language and intercultural competence in the hands of content lecturers, who may not have explicit language and intercultural learning outcomes in mind while it appears that the potential role of ESP as an internationalisation driver may be neglected. This paper thus argues for giving visibility to ESP courses and lecturers in their role for the promotion of curricular internationalisation.

\section{Key words}

internationalisation at home, European higher education, intercultural and international competence, English for specific purposes, English-medium instruction.

* Corresponding address: Elisabet Arnó-Macià, Escola Politècnica Superior d'Enginyeria de Vilanova i la Geltrú, Av Víctor Balaguer 1, Vilanova i la Geltrú, 08800, Barcelona, Spain. 


\section{Sažetak}

U ovom radu analiziramo niz kurseva "internacionalizacije kod kuće" na dodiplomskim studijama, od humanističkih do prirodnih nauka, na državnim univerzitetima u Kataloniji, pružajući dubinsku analizu situacije u južnoj Evropi. Kursevi "internacionalizacije kod kuće" odabrani za analizu uključuju one (i) koji se bave međunarodnim temama, (ii) predaju se na engleskom jeziku i usredsređeni su na sadržaj (nastava na engleskom jeziku), i (iii) usredsređuju se na jezik, tj. engleski jezik nauke i struke. Rezultati ukazuju na visok nivo zastupljenosti kurseva sa međunarodnim sadržajem, naročito u humanističkim i društvenim naukama, iza kojih slede kursevi sa nastavom na engleskom jeziku, mada brojčano retki i uglavnom na tehničkim fakultetima. Kursevi engleskog jezika nauke i struke su najmanje zastupljeni uprkos njihovom potencijalu da pripreme studente za nastavu na engleskom jeziku. Sve u svemu, čini se da trenutna praksa prepušta jezik i međukulturnu kompetenciju predavačima nastavnog sadržaja, koji na umu možda nemaju eksplicitne ishode učenja jezika i međukulturne kompetencije. Istovremeno se čini da se zanemaruje potencijalna uloga engleskog jezika nauke $\mathrm{i}$ struke kao pokretača internacionalizacije. U radu se zalažemo za veću vidljivost kurseva engleskog jezika nauke i struke i njihovih predavača u unapređenju internacionalizacije nastavnih programa.

Ključne reči

"internacionalizacija kod kuće", evropsko visoko obrazovanje, međukulturna i međunarodna kompetencija, engleski jezik nauke i struke, nastava na engleskom jeziku.

\section{INTRODUCTION}

Internationalisation strategies undertaken by universities are expected to enhance students' employability because of the international and intercultural learning opportunities that they should provide, and can be regarded as a "process of integrating an international, intercultural or global dimension into the purpose, functions or delivery of post-secondary education" (Knight, 2004: 11), encompassing the triad of international, intercultural, and global skills (Soria \& Troisi, 2014). Thus, internationalisation extends beyond student mobility, and comprises academic programs as well as extracurricular activities, scholarly collaboration and other external relations (Crowther et al., 2000; Knight, 2004).

In the context of European-wide higher education policies, this study focuses on three types of courses that encapsulate international, intercultural, and global 
competences to gain insight into internationalisation processes in Catalonia (a bilingual community in north-eastern Spain) and, by means of the course categorisation proposed, obtain a picture of how internationalisation is integrated in the curriculum. In particular, this study maps out current internationalised courses in bachelor's curricula across different degrees in Catalan universities. Such wide mapping can inform stakeholders of the status of Internationalisation at Home ( $\mathrm{IaH})$ within emerging internationalisation processes. Implications can be derived from this study that may help other higher education institutions develop further internationalisation policies and actions. Before presenting this analysis, however, it is necessary to briefly introduce the Catalan higher education context and then delve into the concepts of Internationalisation at Home (IaH) and Internationalisation of the Curriculum (IoC).

Similarly to other European institutions, Catalan universities are immersed in internationalisation processes, such as increasing student mobility and developing internationalised curricula or double/joint degrees. Such internationalisation has been boosted by the Bologna process, which led to the creation of the European Higher Education Area (EHEA), characterised by the redesign of curricula based on a student-centered model with the specification of competences and learning outcomes. The ultimate goal of this process was the harmonisation of university degrees across Europe to facilitate mobility. Internationalisation in the context of Catalan/Spanish universities entails developing students' foreign language proficiency, especially English. In this respect, Catalan universities have enforced a foreign language requirement for all bachelor students. Upon graduation, students should demonstrate a B2 level in a foreign language according to the Common European Framework of Reference for Languages (Council of Europe, 2001), a requisite that can be achieved by providing a language certificate or by taking courses (worth at least 9 credits) taught in a foreign language, by participating in a mobility program, or by completing the final thesis in a foreign language (mostly English). ${ }^{1}$ Accordingly, institutional internationalisation plans in Catalonia have set out to promote English-medium instruction (EMI) courses and programs to develop students' proficiency in English through exposure to discipline-specific language (Arnó-Macià \& Mancho-Barés, 2015), in a context with a relatively low presence of English-taught programmes, especially at bachelor's level (Wächter \& Maiworm, 2014). Although EMI has a much greater presence at master's level, this research focuses on bachelor's degrees as it looks into the internationalised curriculum, more comparable across disciplines and universities and more prone to including a wider variety of, and less specialised, subjects than master's degrees.

The role of the English language in curricula internationalisation, mainly through EMI and ESP courses, seems important. University internationalisation in

\footnotetext{
${ }^{1}$ Certification of proficiency in a third language.

http://universitatsirecerca.gencat.cat/en/03_ambits_dactuacio/les_llengues_a_la_universitat/form acio-i-acreditacio-de-terceres-llenguees/\#bloc3.
} 
Europe has emphasised EMI (e.g. Airey, Lauridsen, Räsänen, Salö, \& Schwach, 2017; Coleman, 2006; Doiz, Lasagabaster, \& Sierra, 2011), while less attention has been given to ESP/EAP, with exceptions like Breeze and Sancho-Guinda (2017), who consider EMI and ESP/EAP programmes alike, regardless of whether the focus is on content or on language skills. EMI programmes are aimed to "serve mainly as a means to remove language obstacles for the enrolment of foreign students and for the improvement of international competences of domestic [emphasis added] students" (Wächter \& Maiworm, 2014: 53). Around the year 2000 no more than $10 \%$ of students went abroad to study at a foreign university (Crowther et al., 2000). Although this figure has somewhat increased since then (for example, in Catalonia it was around $19 \%$ for $2014-15)^{2}$, there is a need to cater for the majority of nonmobility students, for whom IaH can be a solution. IaH is conceived of as a set of on-campus activities that promote or create international, intercultural and global understanding, in other words, "any international related activity with the exception of outbound student and staff mobility" (Crowther et al., 2000: 6). Over the years the concept of IaH has been refined to more precisely capture all the elements that contribute to providing graduates with the skills they need to operate in a globalised world (Leask, 2015). A recent definition refers to IaH as "the purposeful integration of international and intercultural dimensions into the formal and informal curriculum for all students within domestic learning environments" (Beelen \& Jones, 2015: 69).

In a study focusing on curricular IaH, it is especially useful to consider the related concept of IoC (Internationalisation of the Curriculum) defined by Leask (2015: 9) as "the incorporation of international, intercultural, and or global dimensions into the content of the curriculum as well as the learning outcomes, assessment tasks, teaching methods, and support services of a program of study." Thus, an internationalised curriculum is related to the development of those skills that will help graduates operate in international settings, such as appreciation of and ability to work in settings of cultural diversity, having a global perspective or adopting international perspectives (Leask, 2015).

Worth mentioning is the assumption underpinning IaH relative to intercultural competences such as understanding, language proficiency, or attitudes (Byram, 2009, 2014; Deardoff, 2009), which should help students develop international and intercultural perspectives as global professionals and citizens (Leask, 2009). Along these lines, Soria and Troisi (2014) found that students in an internationally focused course reported an improvement of global, international and intercultural competencies, showing that students' development of foreign language skills consistently matched that of intercultural competencies, which reinforces the assumption that foreign languages and intercultural skills are interconnected. Although merely changing the language of a course (e.g. EMI) does

\footnotetext{
2 Catalan Association of Public Universities (ACUP) (2016). Education and teaching indicators in Catalan public universities. 2016 Report. Retrieved from http://www.acup.cat/sites/default/files/informe2016.pdf
} 
not render a course international, unless contents and learning outcomes are internationalised (Beelen \& Jones, 2015), EMI forms part of the internationalisation strategy of European universities to increase the institution's international profile, attract international students and develop domestic students' foreign language and international skills (Wächter \& Maiworm, 2014).

This strategy is also espoused by Catalan universities (Mancho-Barés \& ArnóMacià, 2017). Thus, usual statements of intent in many Catalan university policies include - together with (English) language skills - the development of international and intercultural skills to help students become global professionals, a statement clearly connected to the very definition of IoC (Leask, 2015). While internationalisation and language policies of Catalan universities place great emphasis on EMI, they do not usually mention ESP courses (Mancho-Barés \& ArnóMacià, 2017). However, ESP courses can be considered a fundamental part of an internationalised curriculum inasmuch as they are designed to develop the linguistic and intercultural skills that students need to function effectively in international work and study settings (Aguilar, 2018). Foreign language teaching (and thus language teacher education) should be related to intercultural education (Byram, 2014), which, at university level, suggests that ESP courses could play a prominent role in internationalising curricula, somehow acting as a hinge.

This study follows this integrative stance, including both EMI and ESP courses as part of curricular IaH and mapping out the extent of each type of courses. As long as it is based on coherent and well-planned policies, IaH can yield potential benefits (Dunne, 2011; Knight, 2004). For this reason, an internationalised curriculum can prepare students "for performing (professionally, socially and emotionally) in an international and multicultural context" (Nilsson, 2003: 31). However, IaH is not exempt from serious challenges, such as the increased presence of foreign students in the EMI classroom, which places students and lecturers in a new scenario. Lecturing to a culturally diverse classroom in a foreign language may pose problems (Tange, 2010; Teekens, 2003), especially if lecturers are not properly trained and if policies leave it to the individual lecturer to develop an appropriate pedagogy. Of paramount importance therefore is the faculty's commitment to internationalisation and its preparedness to integrate diversity and intercultural issues into their course materials (Mayhew \& Grunwald, 2006), adapt their teaching style, assess international outcomes (Beelen \& Jones, 2015; Leask, 2009), and develop specific skills for the international classroom (Leask, 2015; Sawir, 2011; Tange, 2010; Teekens, 2003). However, the level of English proficiency is one of the main concerns in Spain, one of the European countries with the lowest perceived English proficiency among lecturers and students (Wächter \& Maiworm, 2014) along with low results among the general population (Eurobarometer, 2012). In brief, IaH has received attention across countries, institutions and disciplines, both from top-down perspectives (i.e. recognition of international mission in institutional policies) and bottom-up perspectives (i.e. lecturers integrating an international dimension in their courses). 
IaH research has also looked into disciplinary differences arising from epistemological orientations (Clifford, 2009; Sawir, 2011) or diverse knowledgemaking practices (Kuteeva \& Airey, 2014). Accordingly, this research explores how $\mathrm{IaH}$ is integrated in bachelor's curricula across different subject areas, from engineering to humanities, with special emphasis on the (sometimes hidden) role of ESP as a driver of internationalisation.

\section{THIS STUDY}

This study, set in the context of universities in Catalonia (Spain) and exemplary of the southern European region, is a case in point about the provision of IaH courses at university and excludes other, non-curricular, IaH activities that promote interaction between local and international students. It rests on the assumption that curricular IaH has the potential to develop international and intercultural learning to prepare graduates for multilingual, multicultural environments (Byram, 2009, 2014; Dunne, 2011; Knight, 2004). This analysis can therefore provide policy-makers and course designers with the current state of international courses and suggest what areas need to be addressed in the progressive internationalisation of universities.

Although we are aware that IaH (or IoC) encompasses a myriad of activities dependent on the internationalisation of higher education institutions (Leask, 2015), in this study we focus on one aspect, curricular IaH, viz. those courses in the formal curriculum that specifically address international competences, whether these are linguistic or disciplinary. In relation to $\mathrm{IoC}$, we do not aim at analysing institutional policies from the global perspective of a fully internationalised curriculum (Leask, 2015), i.e. including all the elements from policies to programs, assessment and implementation. Rather, we focus exclusively on those courses that adopt an international perspective in their contents, that aim at developing linguistic and intercultural competences (i.e. ESP courses), or that use English as the medium of instruction (EMI). Hence, three distinct types of courses were selected for analysis, as described below. The first type, International and Intercultural Content (IIC) courses, includes international contents and perspectives in their syllabi and can be considered to raise students' awareness of international issues as they deal with topics related to internationalisation. Therefore, the learning outcomes that would be expected of such courses include appreciation of cultural diversity, consideration of international perspectives and views on the subject, or underlying notions of ethno-relativism. The notion of "international dimension" may be difficult to pinpoint, which is why, for the purposes of this study, we considered IIC courses those that specifically included terms like "international", "(inter/multi)cultural" or "cultural relativism" in their syllabi. 
The second type of courses refers to those taught in English (EMI), considering that the provision of EMI courses is one of the key strategies in internationalisation in European universities inasmuch as they facilitate the presence of foreign students in the classroom and may help domestic students develop competences for the globalised marketplace.

The third type of courses includes English for Specific Purposes courses, which focus on language and communication related to academic and disciplinary needs, address intercultural communication and prepare students to operate in multilingual settings. The latter two courses (EMI and ESP) are based on language of instruction and can be related to Greere and Räsänen's (2008) model of integration of language and content, in that both would correspond to Pre-CLIL courses, the former being 'Pre-CLIL content' courses and the latter, 'Pre-CLIL language' courses. The rationale behind this characterisation is discussed below.

\subsection{A model for the integration of content and language in higher education}

In this characterisation of IaH courses, it is key to identify those courses that incorporate language and content, specifying what we consider EMI vs. ESP. We follow Greere and Räsänen's (2008) model of content and language integrated learning (CLIL) in higher education, which sets forth five typologies as a continuum across two criteria: first, focus of instruction (language vs. content) and, second, the extent of their integration. At one end of the continuum, there are Language for Specific Purposes (LSP) courses, discipline-based language courses given by language specialists. LSP is followed by 'Non-CLIL' courses, taught by content lecturers, with $<25 \%$ of exposure to the foreign language, usually unsystematic and incidental. On the other hand, in terms of integration of language and content, 'PreCLIL' courses can be classified into 'content courses' (without specified language learning outcomes, and with $>25 \%$ of exposure to the foreign language), and 'language courses', which prepare students for content courses with input from content specialists. Further integration involves 'adjunct CLIL teaching', i.e. content instruction in coordination with language specialists, followed by CLIL, i.e. full dual integration of language across subject teaching.

Using Greere and Räsänen's (2008) model as a point of departure, we propose some adaptations to accommodate it to the context of Catalan universities. Since, to the best of our knowledge, there are virtually no 'Adjunct CLIL' or 'CLIL' courses in Catalan universities (Aguilar, 2017), we analyse those courses that fall on both ends of the non-integration continuum, namely, ESP and English for Academic Purposes (EAP) courses as instances of LSP courses (in Greere and Räsänen's terms), and Pre-CLIL content courses (labelled EMI courses, offering $>25 \%$ of exposure to the foreign language). Pre-CLIL language courses (if any), in our study, would be subsumed within the general LSP label, as this study takes a 
broad approach to ESP, including all language courses, regardless of their specificity. A type of course that does not constitute our focus of analysis but that is considered a backdrop for comparison with EMI courses is what Greere and Räsänen label non-CLIL courses (i.e. < 25\% of exposure to English), which we labelled non-EMI courses, as the use of the English language in them can lead to further reflection on EMI and ESP provision.

In turn, our adaptation of Greere and Räsänen's (2008) model, especially considering the two ends of focus on content and focus on language, holds parallel with Airey's (2016) continuum between EAP and EMI courses, based on whether the focus is on language, content, or there is integration of both (with CLIL at the middle point).

\subsection{Objectives and methodology}

Our characterisation of IaH programs follows Knight (2004) and Dunne (2011) in that they are either taught in English (like ESP and EMI courses) or include international topics, regardless of the language of instruction. Accordingly, this study analyses curricular IaH across disciplines, considering the presence of three types of international courses in bachelor's degrees:

- Courses including international content/topics which aim at "broadening traditional programs through an internationally comparative approach, offering international subject matters like international relations, European law, etc." (Wächter \& Maiworm, 2014: 86). Despite the growing number of internationalised programmes in southern Europe, to our knowledge their presence in Spanish universities has not yet been investigated, let alone the presence of international content courses vis-à-vis English-taught courses.

- Courses that incorporate the foreign language (usually English) and help prepare students for international settings:

- EMI courses, on the grounds that exposure to the foreign language can develop students' discipline-related language skills and intercultural skills.

- ESP/EAP courses, because of their aims to cover discipline-specific skills, genres and discourse, and address intercultural communication issues.

It is important to mention that the above characterisation of international courses has been made according to the context being studied, in which EMI and ESP play an important role in developing students' language competence in relation to the discipline. In other contexts, for example, in Australia, IaH courses may include awareness-raising and fostering intercultural competence through practical skillsbased modules integrated in regular courses, thus taking advantage of existing multicultural classrooms (e.g. Barker \& Mak, 2015). In our view, the definition of 
internationalised courses should be adapted to each context so that it becomes meaningful to stakeholders. Accordingly, our definition - narrow though it may seem - appears meaningful in the context studied, given the recent impulse towards internationalisation and the promotion of English language skills among university students.

\section{ANALYSING INTERNATIONALISATION AT HOME (IaH) COURSES}

IaH courses were analysed by examining a sample of the bachelor's degrees offered by the seven public universities in Catalonia: Universitat Autònoma de Barcelona (UAB), Universitat de Barcelona (UB), Universitat de Girona (UdG), Universitat de Lleida (UdL), Universitat Politècnica de Catalunya (UPC), Universitat Pompeu Fabra (UPF), and Universitat Rovira i Virgili (URV).

\begin{tabular}{|c|c|c|c|c|c|c|c|c|}
\hline AREA & Degree & UAB & UB & UDG & UDL & UPC & UPF & URV \\
\hline \multirow{2}{*}{$\begin{array}{l}\text { Arts } \\
\& \text { Humanities }\end{array}$} & History / Humanities & & & & & & & \\
\hline & Geography & & & & & & & \\
\hline \multirow{2}{*}{ Science } & $\begin{array}{l}\text { Food Science and } \\
\text { Technology }\end{array}$ & & & & & & & \\
\hline & Chemistry & & & & & & & \\
\hline \multirow{2}{*}{ Social Sciences } & Law & & & & & & & \\
\hline & Social Education & & & & & & & \\
\hline \multirow{2}{*}{ Health Sciences } & Psychology & & & & & & & \\
\hline & Nursing & & & & & & & \\
\hline \multirow{2}{*}{ Engineering } & Computer Engineering & & & & & & & \\
\hline & Mechanical Engineering & & & & & & & \\
\hline
\end{tabular}

Note: Shaded cells indicate that a particular degree is not offered, and two degrees separated by a stroke (e.g., History/Humanities) means that the same degree was not offered at all universities and therefore a similar degree was analysed.

Table 1. Bachelor's degrees analysed across universities

This sample is representative, not only because it covers all public universities in Catalonia, but especially because it compares degrees across a wide range of discipline areas. Accordingly, ten different bachelor's degrees were chosen to cover 
the following discipline areas: Arts and Humanities, Science, Social Sciences, Health Sciences, and Engineering. Two degrees were selected for each of the five areas. These ten degrees were studied across all seven universities, which yielded a figure of 56 degrees analysed (considering that not all degrees were offered at all universities). Table 1 summarises all the degrees analysed, together with their discipline and the universities where they were offered.

Although our study focuses on the degrees offered by different universities, we were interested in observing trends across disciplines rather than investigating the idiosyncrasies of each university. Data consisted of the public course descriptions from university websites, which were collected and systematised by the OPUC, the Observatory on Plurilingualism in Catalan universities (Observatori del Plurilingüisme de les Universitats Catalanes, http://www.opuc.udl.cat/), dependent on the research group that the authors belong to. The OPUC website is a database providing public information from Catalan universities that has been organised and classified to make it available to researchers and policy-makers for analysis and decision-making. The OPUC's "analysis documents" consist of tables classifying (and hyperlinking) different course descriptions.

For the first type of IaH courses analysed, IIC courses were selected on the basis of their title and course description, which had to include intercultural or international topics. The qualitative analysis of the course consisted in identifying those topics in course syllabi that could be classified as internationalised, based on Leask's (2015) criteria for an internationalised curriculum: contents that (i) incorporate international perspectives and viewpoints, and (ii) learning outcomes aimed at developing international/intercultural competences and attitudes. Thus, these general criteria - without further specifying the degree of internationalisation of each course - helped determine which courses included, to a certain extent, an international perspective. More specifically, the analysis considered whether those contents were substantiated by learning objectives/expected outcomes that foster students' appreciation of interculturality/internationalisation. Further analysis also identified the approach taken to IIC - i.e. the nature of the IIC contents covered, whether they focus on cultural differences or refer to international/comparative legislations, for example. Below is a list of example courses, each accompanied by some of their IIC contents and learning outcomes:

- Urban Cultures (Geography): Course objectives ('This course aims to foster critical reflection about the diversity of urban cultures and ways of investigating it'), theoretical contents (e.g. 'The central city: The Chicago School. /The peripheral city: The Mexico School') and practical activities (e.g. Seminar about the city and cinema, with topics such as 'The city in history: Paint your wagon/Roma', 'The central city: A Bronx tale / Do the right thing') are aligned with IIC, promoting critical reflection on cultural diversity and integrating a variety of international perspectives.

- Reception and Integration of Immigrants (Social Work): Course objectives place emphasis on developing students' awareness of multicultural societies '... 
understanding the complexity of migratory processes and their management in current society, identifying some of the main problems inherent to reception and inclusion of immigrants in multicultural societies'.

- Culture, Society and Health (Nursing): IIC contents (e.g. 'cultural relativity of the concepts of "health", "illness", "pain" and "death", "social and cultural construction of health and illness"') and course objectives are rooted in the analysis of different views on health and death within the cultural diversity of the country.

- Anthropology of Health and Multiculturality (Nursing): IIC contents ('health, illness, pain and death from the perspective of different cultures. Prescriptions and prohibitions of each culture') and course objectives ('develop critical knowledge and an open attitude towards cultural diversity in the processes of health-illness-care').

With regard to EMI courses, the analysis took into account those courses in which English was the language of instruction (following Greere and Räsänen's (2008) model, Pre-CLIL courses, > 25\% of use of English).

On the other hand, ESP courses included both English for General Academic Purposes (which could involve a course shared across different disciplines, e.g. on academic writing), and discipline-related ESP courses.

\section{PRESENCE OF INTERNATIONALISATION AT HOME (IaH) COURSES}

This section summarises the presence of the three types of IaH courses in the different degree areas, (i) ICC courses, (ii) EMI courses, and (iii) ESP courses. For IIC and ESP, results are presented as to which degrees (and degree areas) contain such courses - regardless of the number of courses in each. On the other hand, for EMI courses, the exact number of courses is specified. Considering that institutional policies promote the implementation of EMI, we were particularly interested in finding out the specific number of EMI courses, which can inform us of the situation of EMI across different discipline areas.

\subsection{International and intercultural content (IIC) courses}

The presence of IIC courses in the different degrees is summarised in Table 2. This category includes courses with international/intercultural contents, even if those are not the main focus of the course - sometimes they may constitute less than half of the contents covered. 


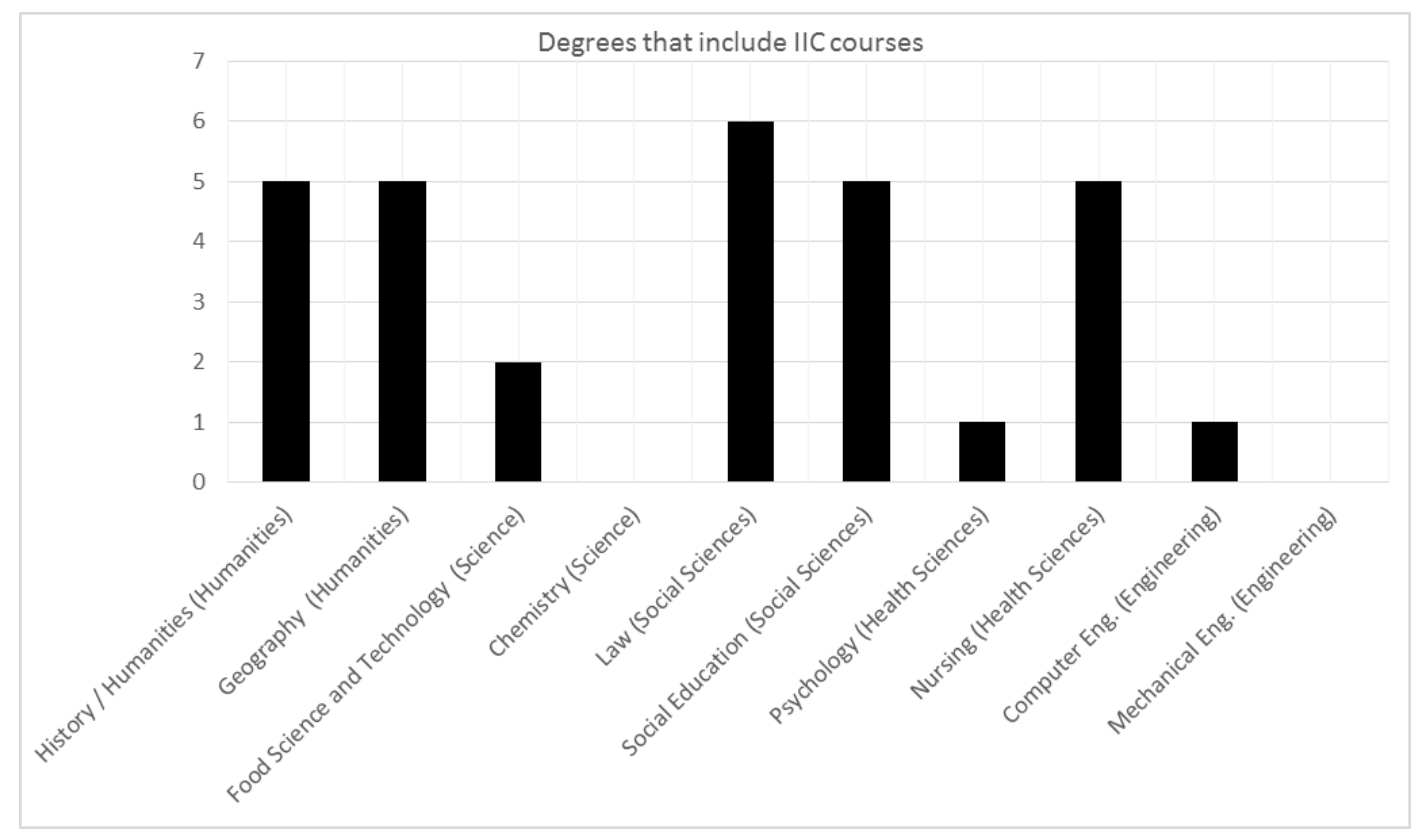

Table 2. IIC courses across degrees and disciplines (Arts \& Humanities, Science, Social Sciences, Health Sciences, Engineering)

Most IIC courses are found in Humanities and Social Sciences. This trend coincides with Wächter and Maiworm's (2014) observation that Social Sciences and Health and Welfare are disciplines more prone to preparing students for international professions, with $99 \%$ and $91 \%$ of degrees oriented towards internationalisation, respectively (although it should be noted that Wächter and Maiworm examine English-taught programmes, and in this study we analysed IIC courses regardless of their language of instruction). On the other hand, we hardly found any International and Intercultural content courses in Engineering or Science degrees except for one Computer Engineering degree and two Food Science and Technology degrees. Besides, the analysis of the approach to IIC further revealed differences between areas, with Humanities and Social Sciences including subjects on international and/or intercultural human relations like Health Anthropology and Multiculturality (Nursing) or Public International Law. On the other hand, international/intercultural contents are incidental in Engineering and Science, in which case they are part of broader courses oriented towards the professional field, like 'Introduction to the food sector' (Food Technology) or 'Legal, Social and Professional Aspects' (Computer Engineering), which cover common European legislation.

Disciplinary differences may indicate different epistemological orientations, knowledge-making practices and educational goals (Clifford, 2009; Sawir, 2011). Hard science lecturers may be less open to integrating international/intercultural themes because they consider their discipline to be international, based on value- 
free universal principles (Kuteeva \& Airey, 2014), while lecturers from Humanities and Social Sciences are more sensitive to the integration of generic competences and a more interactive pedagogy in culturally diverse classrooms (Clifford, 2009). Health Sciences is found in-between the two extremes, with more international courses in Nursing than in Psychology.

Overall, our results align with trends in Europe regarding the number of internationalised courses, a documented "frequent characteristic of curricula of Bachelor programs in most regions” (Wächter \& Maiworm, 2014: 91).

\subsection{Using English as the language of instruction: EMI courses}

The second strand in this study covers English-taught courses, EMI and ESP. For the analysis of EMI courses, all course descriptions in each curriculum were examined to identify English-taught courses. The documents were analysed to find out whether they indicated that English was the language of instruction, and when it was specified, the percentage of use of the foreign language - distinguishing EMI $(>25 \%)$ from Non-EMI (<25\%) courses. For example, a course description ('Spectroscopy') indicated that the language of tuition was mostly English. Another description, of a law course, indicated that the main language used in class was English and further specified the percentages of language use in speech and in writing, as shown below:

Main language used in the classes: English

- Spoken English is used in the course: Completely (100\%)

- Documents in English are used: Mostly (75\%) ${ }^{3}$

Despite our focus on EMI, we also included those courses that indicated some incidental use of English (e.g. reading documents or requiring students to produce outputs in English). It was, however, difficult to specify the type of exposure that each course involved, as English could also be used in learning activities or assessment, and course descriptions do not usually provide extensive information about the teaching and learning methods used. Without going further into the analysis of non-EMI courses, we used them as a benchmark to gauge the presence of EMI courses vis-à-vis the total number of courses that use English to some extent. A quantitative analysis revealed that there were only 44 EMI courses in total (Table 3), a low figure considering that we examined 56 degrees (yielding an average of less than one EMI course per degree). Engineering was the area with the

\footnotetext{
3 Source: Course description for a law course. Retrieved from http://www.udg.edu/Guiadematricula/Dissenyassignatura/tabid/15700/Default.aspx?curs=2011 \&codia=3104G00001\&codip
} 
highest presence of EMI courses (15), whereas across the rest of the disciplines we could find lower figures, quite evenly distributed, with a slightly lower number in Science.

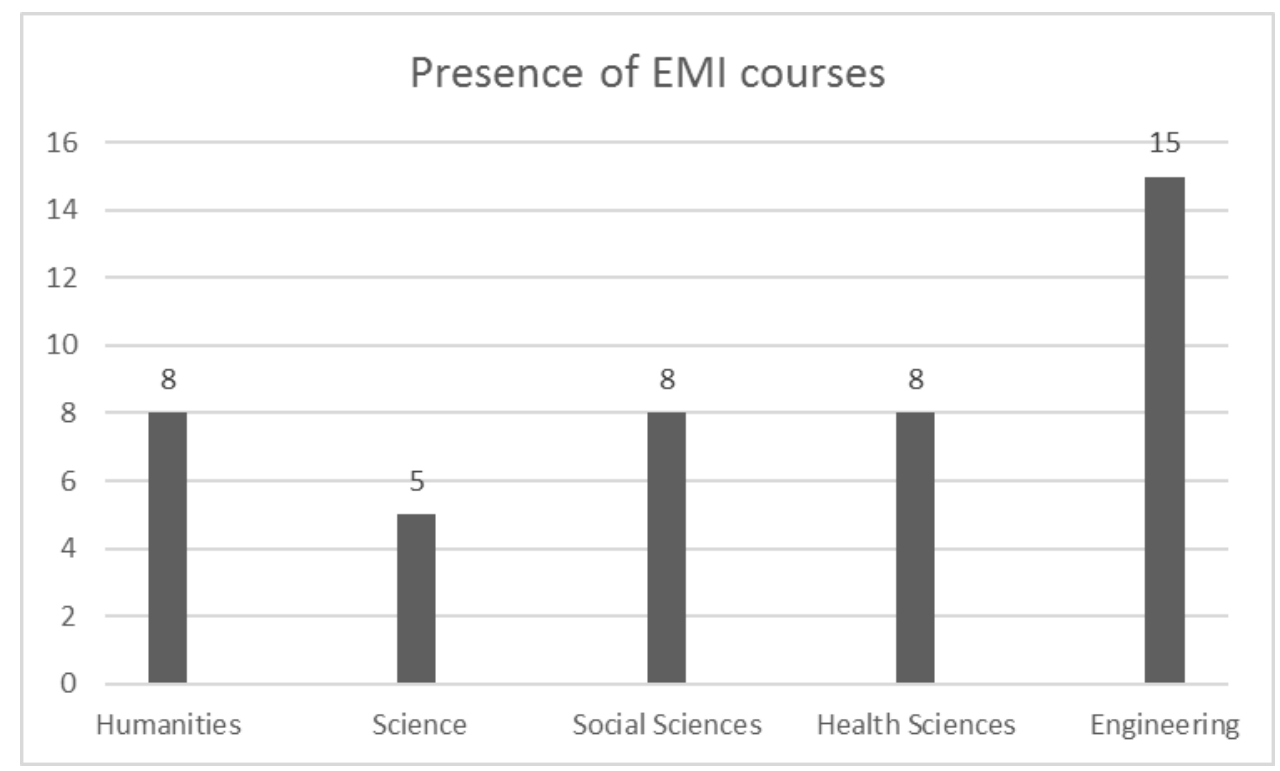

Table 3. Number of EMI courses and distribution across disciplines

The number of EMI courses can be considered low, especially if contrasted with the presence of over 500 courses that included $<25 \%$ in English, mainly in the Humanities. Although non-EMI courses are not the object of this study, they are taken as a reference for comparison with EMI and to obtain an indication of the integration of the English language in university teaching in Catalonia. These results indicate that EMI courses do not have a real presence in bachelor's degrees in our context, but rather that universities (through top-down policies) or stakeholders, like departments or individual lecturers (through bottom-up practices) recognise the importance of English. It should be noted that despite the promotion of EMI in the commitment of institutional policies to attracting international students, in the Spanish university context, foreign students are sometimes drawn to courses taught in Spanish, motivated by their willingness to learn the language during their stay.

Such a scarce presence of EMI courses contrasts with the high number of non-EMI courses, indicating a certain attempt to bring English into the classroom. A closer look at the courses across universities shows that most non-EMI courses are offered by one university, UdG (University of Girona), with a total of 384 courses (with 229 in Humanities). Such a large number of courses may be due to a greater commitment by that university towards integrating English into teaching. A more likely reason may be the format of the course description template, which includes a section that specifies the percentage of use of English (which may be as 
low as $5 \%$ or $2 \%$ ) and the presence of the generic communication competence 4 and academic literacy in English - with descriptors such as 'using the English language' or 'being able to communicate in speech and writing in the scientific and professional domain, using one's own languages and English'. A question that remains unanswered is whether the real number of non-EMI courses is in fact higher, as this may not always be visible. Non-EMI courses deserve further attention as they could be considered the first step towards the internationalisation of curricula for lecturers and students who may not be fully prepared for intensive EMI courses. Time will tell whether non-EMI courses are a kind of stepping stone to a growing number of true EMI courses. Whether or not that is the case, such specific inclusion of English in academic activity (and especially, ESP-like descriptions like the abovementioned item 'being able to communicate [...] in the scientific and professional domain') would certainly lay the ground for ESP intervention, either in the form of tandem-teaching or adjunct courses. Therefore, one of the challenges for both EMI and ESP lecturers alike is the crossing of disciplinary and departmental boundaries.

\subsection{Using English as the language of instruction: ESP courses}

The presence of ESP courses is also scarce, as they are included in only 15 degrees (out of 56). However, these results should be taken cautiously because such courses are often elective and may not be visible in the general curriculum description, which sometimes only lists compulsory courses (an indicator, in turn, of the invisibility of ESP tuition in this context). Table 4 summarises the presence of ESP in the different degrees. At this point, it should be mentioned that ESP courses were not analysed individually, but we focused on the number of degrees that contained ESP courses (without specifying the number of courses in each). The reason for this was that, on the one hand, most ESP courses are elective and, therefore, their offer may be less consistent than that of compulsory courses. Besides, their elective nature may make them less visible than compulsory courses. On the other hand, a general overview of the presence of ESP courses in a particular degree (regardless of the number of such courses) is enough to map out the different ESP trends across disciplines and universities. Our analysis reveals that ESP is not being prioritized through course offerings, in keeping with university policies that favour EMI as one of the main internationalisation strategies (e.g. Mancho-Barés \& Arnó-Macià, 2017).

\footnotetext{
${ }^{4}$ As a result of the Bologna process, learning outcomes in university degrees in Europe are specified in the form of generic and specific competences. See the Tuning Project for a detailed account of generic/specific competences (González \& Wagenaar, 2003).
} 


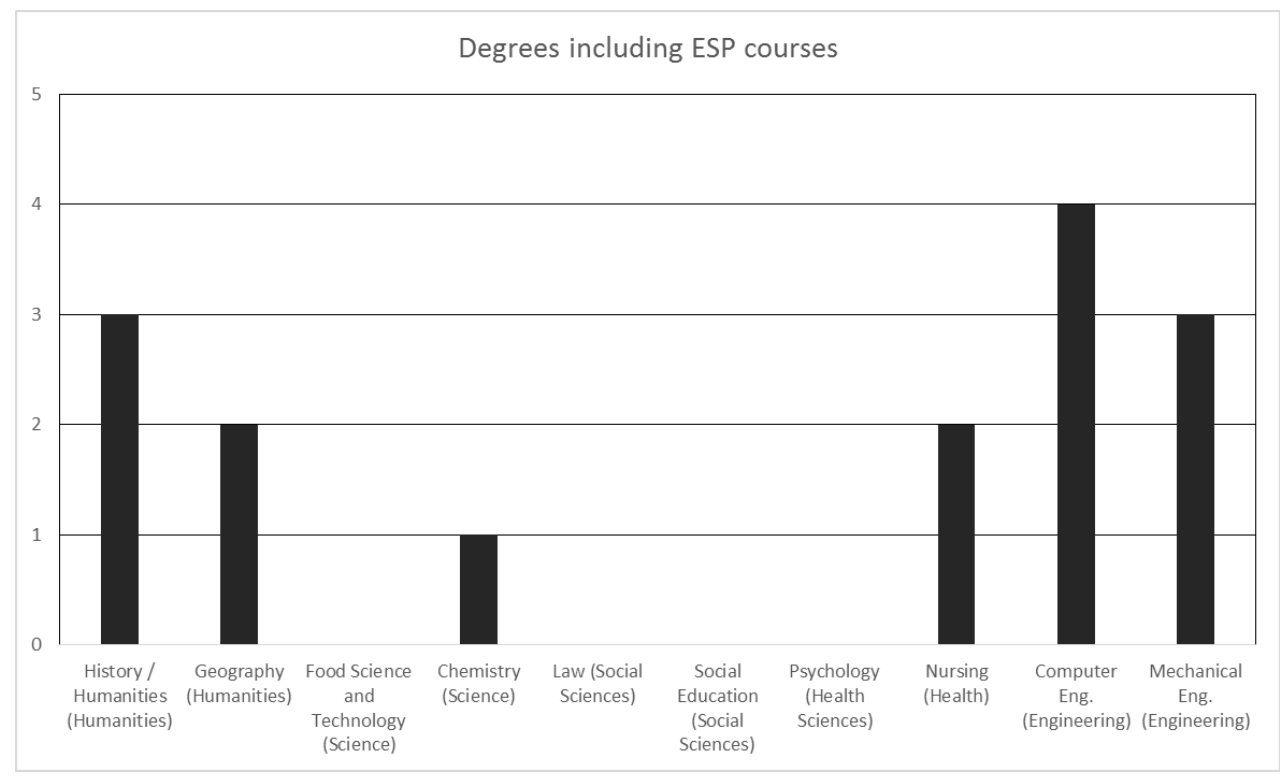

Table 4. Presence of ESP courses across degrees and degree areas

These figures show that ESP courses are mainly found in Engineering and Humanities, specifically in seven Engineering degrees (50\%) and in five Humanities degrees (45\%). These results can be interpreted, on the one hand, from the point of view of the traditional presence of ESP in Engineering degrees. Historically, ESP courses started with the teaching of English for Science and Technology (Swales, 1985). Therefore, it is not surprising to find a higher number of ESP subjects in these disciplines, although with the redesign of curricula as a result of the Bologna process in European higher education, in some universities ESP courses were kept and in others they were replaced with EMI courses. In contrast, in those degrees where ESP had not been customary (e.g. Law), the internationalisation of curricula did not bring about the introduction of ESP. The case of Humanities is somewhat different, as language use and written and oral expression are inherent parts of the field. Five degrees contain EAP, either as a common core course shared across degrees or as degree-specific courses, in addition to other languages for specific-purposes courses like French or German, as well as academic writing courses in Catalan or Spanish.

The reason why ESP courses are completely absent from Social Sciences degrees and only appear in one Science degree (Chemistry) could be explained by the lack of ESP tradition in those areas. On the other hand, ESP appears in two Health degrees (Nursing degrees at two different universities), which can presumably be linked to the ESP tradition in the medical field (Dudley-Evans \& St. John, 1998). The number of ESP courses in Health Sciences is lower than expected, though. A closer analysis of one of the Nursing curricula (from UB, Catalonia's largest university) reveals that there are no ESP courses, but there are some English-taught content courses as well as communication-focused courses (designing presentations, specialised documents, interviews), taught in Catalan or Spanish. A 
plausible explanation for this may be that the redesign of curricula led to the introduction of EMI as a way of introducing English language competences, while the communication competences were already covered by the communication courses (or integrated in content courses).

From this picture, it appears that the inclusion of ESP courses probably stems from the position that such courses previously occupied in pre-Bologna degrees, often associated with the presence of ESP lecturers in the different schools. With curricular changes, ESP seems to have arrived at a situation of 'fragility' (Swales, Barks, Ostermann, \& Simpson, 2001), with the paradox that increasing internationalisation, leading to greater use of English as a lingua franca, results in ESP courses having an ancillary (if any) role in many degrees. The underlying assumption appears to be that there is no need to train students in ESP either because specialised communication can be learnt via EMI courses or that language learning comes in the form of extracurricular courses (language services), which reflects a not so uncommon situation in Europe (Fortanet \& Räisänen, 2008).

\subsection{Summary of results}

Taken together, the results from the three types of courses analysed yield the following picture (Table 5), indicating the number of degrees that contain different types of IaH courses, distributed across disciplines. Considering that the total number of degrees analysed is 56 , the percentage of degrees containing curricular IaH is the following: $55 \%$ for IIC courses, $41 \%$ for EMI courses, and $27 \%$ for ESP courses. As can be seen, many degrees include more than one type of internationalised courses, mostly IIC and EMI, while the presence of ESP is scarcer.

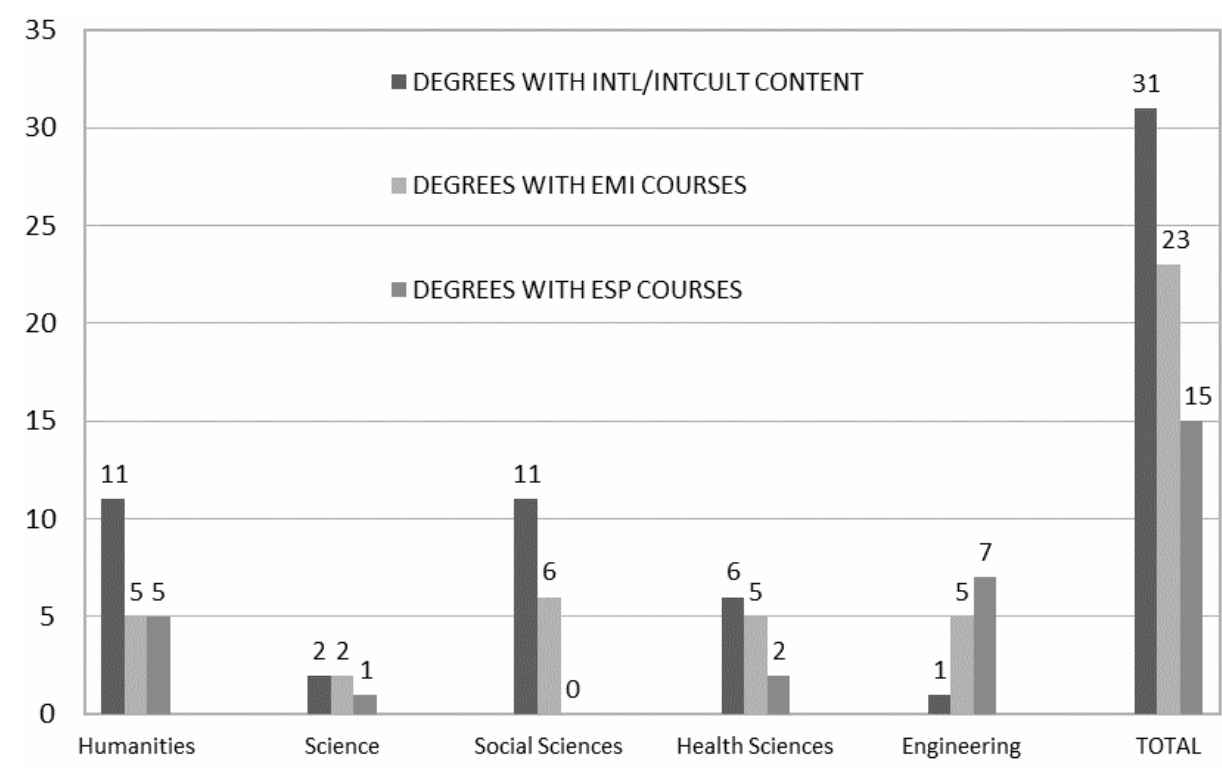

Table 5. Overall results for the three types of international courses analysed 
These figures point to the importance attributed to IaH by the different universities. The highest presence of IIC courses may have to do with the disciplines involved, Humanities and Social Sciences. This partly substantiates Wächter and Maiworm's study (2014) in that the soft sciences show the highest percentage of international courses, applied hard sciences (Health Sciences and Engineering) come second, and pure hard sciences show the lowest percentage. On the other hand, the number of EMI courses is rather low, especially if compared with the much higher number of courses that include some use of English (nonEMI courses): $>500$ non-EMI vs. 44 EMI courses. The presence of EMI courses is quite even across all areas (with a lower presence in Science). Even if scarce, the presence of EMI (together with that of non-EMI) courses indicates some awareness of the need to introduce English. Thus, we should take into account two relevant points related to Spain from Wächter and Maiworm's (2014) study: (i) a generally low English proficiency level among Spanish lecturers and (ii) international students' proficiency in Spanish (or motivation to learn Spanish). This combination of low proficiency levels and the use of a major language may lead to internationalisation being done in Spanish rather than English. Besides, the decision to implement EMI courses is usually taken by individual lecturers or departments, rather than by institutional policies (Dafouz, Camacho, \& Urquia, 2014; Mancho-Barés \& Arnó-Macià, 2017), which could help explain such a haphazard picture.

Regarding the general distribution of IaH courses across disciplines, we find that Science degrees have the lowest presence of IaH courses. From this picture, one gets the impression that IIC courses have not been designed with a specific internationalisation intention in mind. In a recently internationalised university context such as that of Spanish higher education, one finds the lack of a clear rationale for the true internationalisation of the curriculum, which would call for lecturer training and explicit commitment to the integration of IIC (Mayhew \& Grunwald, 2006; Tange, 2010; Sawir, 2011). Principled approaches to integrating internationalisation and interculturality would benefit from the contributions of ESP lecturers, expanding their role as "intercultural brokers" (Bocanegra-Valle, 2015) beyond the ESP classroom.

\section{CONCLUSIONS, IMPLICATIONS, AND FURTHER RESEARCH}

The somewhat random distribution of IIC, EMI and ESP courses across degrees could be explained in part by the processes of internationalisation and curriculum redesign in Europe. Like other South European regions, Catalan (and Spanish) universities have only recently embarked on internationalisation, or rather towards Englishisation (e.g. Lasagabaster, Cots, \& Mancho-Barés, 2013), a dominating trend in European higher education (Coleman, 2006). In this context, the presence of IaH courses at Catalan universities does not seem to stem from an 
explicit plan - except perhaps for EMI courses, which appear in institutional policies as a tool for internationalisation, but whose eventual implementation depends on the initiative of departments or even individual lecturers. In any case, the findings obtained in this analysis do not seem to result from an explicit intention of promoting $\mathrm{IaH}$ or an institutional process of developing a fully integrated IoC as described by Leask (2015), i.e. one that takes into account all the elements of the curriculum.

In the context of Catalan universities, our results can inform decision-makers on the current state of international courses, so that they can take advantage of existing resources and define policies to advance further on the IaH agenda of each institution. Additionally, recent trends in student mobility (European Commission, 2015) reveal that Social Sciences make up the biggest share, followed by Arts and Humanities. This internationalisation indicator would point to two possible explanations for curricular IaH. On the one hand, the more internationalised disciplines are, the higher the student mobility rate. On the other hand, those disciplines with the lowest numbers of student exchanges could then compensate for low student mobility rates by increasing the number of IaH courses, such as IIC, EMI and ESP, to ensure that students become prepared for global workplaces. Explicit IaH policies based on a thorough analysis of multiple internationalisation indicators (the present study being one of them) are thus necessary to yield a picture of the status quo regarding the presence of different IaH courses across degree areas.

Results of the presence of IIC courses indicate that these are mostly found in subjects that involve intercultural/international perspectives in Humanities and Social Sciences degrees. Therefore, IIC contents seem to emerge from the nature of the courses themselves (e.g. international law, socio-cultural perspectives on nursing, etc.) rather than from the intentional process of internationalisation. These results, from a context of emerging internationalisation, can be useful to draw stakeholders' attention to fostering further - intentional - internationalisation of the IIC courses identified to ensure that they do develop students' international skills (which is not guaranteed by merely including international topics). A case in point may be the example of Sweden, where courses similar to the IIC courses studied (transnational nursing and social policies in Europe) have been approached from a skills-based practical orientation towards developing students' international skills (Rosner \& Christensen, 2016).

On the other hand, the scarce presence of EMI courses may point to the difficulty in their implementation - despite their promotion through institutional policies (Mancho-Barés \& Arnó-Macià, 2017). This situation may be due to lecturers' and students' perceived low proficiency levels, lack of clear institutional planning, with EMI courses left at the goodwill of lecturers (Dafouz et al., 2014), and a lack of institutional incentives (Arnó-Macià \& Mancho-Barés, 2015). In any case, the use of English as a medium of instruction to a greater or lesser extent EMI and non-EMI courses - points to a concern for internationalisation and the 
development of discipline-specific language proficiency. Considering that EMI is relatively new in our context, it may be surprising to find that even if the number of EMI courses is not particularly high, they outnumber ESP courses with a much longer tradition. A related question would be whether ESP is on the decline. Corroborating the picture painted by Fortanet and Räisänen (2008) in Europe, it appears that EMI is at the very least overshadowing ESP, if not replacing it, which would be quite paradoxical, given the importance assigned to discipline-specific communication by university policy-makers. Traditionally the domain of ESP courses, the development of discipline-communication skills now appears to be an objective assigned to EMI courses, probably perceived as more 'useful' than ESP courses to trigger authentic communication. Thus, apart from policies favouring the implementation of EMI as a means to develop students' discipline-specific language skills, the view that EMI is growing at the expense of ESP is reinforced by the findings of a previous study set in the same context, with both students and lecturers favouring EMI as an efficient way of introducing English in the curriculum, as opposed to ESP, viewed as 'traditional' language courses (ArnóMacià \& Mancho-Barés, 2015). In this scenario, ESP courses, which (unlike EMI) are not explicitly addressed by internationalisation policies, 'survive' in new curricula depending on their traditional presence and on the question of how much room can be made in new curricula for 'ancillary' subjects like languages (an explanation that stems from the elective nature of ESP courses), and which takes us back to Swales et al.'s (2001) notion of 'fragility'. Such a view, together with the apparent lack of coordination between content and language lecturers, neglects the potential of ESP (especially EAP) to prepare undergraduate students for participation in EMI (Terraschke \& Wahid, 2011), to hone their disciplinary academic skills through situated EAP teaching (McGrath \& Kaufhold, 2016), and to raise awareness about intercultural communicative competence while teaching English for specific purposes (Aguilar, 2018). Considering the weight that content courses have in new curricula, and the unequal power relations between large departments responsible for disciplines that are central to the degree and the limited number of ESP faculty available, it is not surprising to find ESP being overshadowed by EMI. Besides, the risk remains that EAP/ESP lecturers work 'for' (rather than 'with') content lecturers (Hyland, 2012). At this point, a further longitudinal study should corroborate whether there is such an upward trend in EMI and decline of ESP in Spain. In turn, from a broader perspective, it would be interesting to investigate whether such a trend is also found in other European countries.

The fact that IIC courses are almost exclusively found in Humanities and Social Sciences degrees - in those courses which lend themselves to international topics - together with the fact that IIC are scantly mentioned in institutional policies, indicates that IIC neither stems from planning nor is exploited to its full potential. Further research should look at IIC courses in more detail, first to see how they can truly contribute to developing students' international, intercultural 
and global competencies and, second, to see how ESP lecturers can make the most of multicultural classrooms, on the grounds that "internationalization is not merely about incorporating international elements in the curriculum, it is about being open to alternative ways of thinking" (Sawir, 2011: 54).

In sum, with EMI as universities' flagship curricular action, policies leave both language and IIC in the hands of content instructors, and somehow neglect ESP lecturers, who have traditionally taken the role of integrating content and boosting international and intercultural awareness. The IaH curriculum analysed in this study does not seem to be linked to core institutional objectives promoting intercultural and international culture and knowledge. This analysis of the three types of IaH courses can shed light on directions to be taken to make the most of existing courses and resources and ensure that most students can benefit from IaH, promoting the integration of local and international students and preparing them for globalised work and study settings.

[Paper submitted 13 Jul 2018]

[Revised version received 9 Oct 2018]

[Revised version accepted for publication 7 Nov 2018]

\section{Acknowledgement}

This work was supported by the Ministry of Economy and Competitiveness of Spain under Grant [FFI2012/35834]; Autonomous Government of Catalonia under Grant [2014 SGR 1061], and Ministry of Economy and Competitiveness of Spain under Grant [FFI2016-76383-P]. We are also indebted to our colleague, Dr. Guzman Mancho-Barés, director of OPUC, for his help with the database and his useful advice when we started the research for this paper.

\section{References}

Aguilar, M. (2017). Engineering lecturers' views on CLIL and EMI. International Journal of Bilingual Education and Bilingualism, 22, 722-735. https://doi.org/10.1080/13670050.2015.1073664

Aguilar, M. (2018). Integrating intercultural competence in ESP and EMI: From theory to practice. ESP Today, 6(1), 25-43. https://doi.org/10.18485/esptoday.2018.6.1.2

Airey, J. (2016). EAP, EMI or CLIL? In: K. Hyland, \& P. Shaw (Eds.), The Routledge handbook of English for academic purposes (pp. 71-83). London: Routledge.

Airey, J., Lauridsen, K. M., Räsänen, A., Salö, L., \& Schwach, V. (2017). The expansion of English-medium instruction in the Nordic countries: Can top-down university language policies encourage bottom-up disciplinary literacy goals? Higher Education, 73, 561-576.

Arnó-Macià, E., \& Mancho-Barés, G. (2015). The role of content and language in content and language integrated learning (CLIL) at university: Challenges and implications for ESP. English for Specific Purposes, 37, 63-73. 
Barker, M. C, \& Mak, A. S. (2015). The business of intercultural competence development. In W. Green, \& C. Whitsed (Eds.), Critical perspectives on internationalising the curriculum in disciplines. Reflective narrative accounts from business, education and health (pp. 73-82). Rotterdam: Sense Publishers.

Beelen, J., \& Jones, E. (2015). Redefining internationalization at home. In A. Curaj, L. Matei, R. Pricopie, J. Salvi, \& P. Scott (Eds.), The European higher education Area (pp. 5972). New York: Springer.

Bocanegra-Valle, A. (2015). Intercultural learners, intercultural brokers and ESP classrooms: The case of a shipping business course. Procedia. Social and Behavioral Sciences, 173, 106-112

Breeze, R., \& Sancho Guinda, C. (Eds.) (2017). Essential competencies for English-medium university teaching. Cham, Switzerland: Springer International Publishing.

Byram, M. (2009). Intercultural competence in foreign languages. The intercultural speaker and the pedagogy of foreign language education. In D. Deardoff (Ed.), Sage handbook of intercultural competence (pp. 321- 332). Thousand Oaks, CA: Sage.

Byram, M. (2014). Twenty-five years on: From cultural studies to intercultural citizenship. Language, Culture and Curriculum, 27, 209-225.

Catalan Association of Public Universities (ACUP) (2016). Education and teaching indicators in Catalan public universities. 2016 Report. Retrieved from http://www.acup.cat/sites/default/files/informe2016.pdf

Clifford, V. A. (2009). Engaging the disciplines in internationalising the curriculum. International Journal for Academic Development, 14, 133-142.

Coleman, J. (2006). English-medium teaching in European higher education. Language Teaching, 39, 1-34.

Council of Europe (2001). Common European framework of references for languages. Cambridge: Cambridge University Press.

Crowther, P., Joris, M., Otten, M., Nilsson, B., Teekens, H., \& Wächter, B. (2000). Internationalisation at home: A position paper. Amsterdam: European Association for International Education.

Dafouz, E., Camacho, M., \& Urquia, E. (2014). 'Surely they can't do as well': A comparison of business students' academic performance in English-medium and Spanish-as-firstlanguage-medium programmes. Language and Education, 18, 223-236.

Deardoff, D. (2009). The SAGE handbook of intercultural competence. Thousand Oaks, CA: Sage.

Doiz, A., Lasagabaster, D., \& Sierra, J.M. (2011). Internationalisation, multilingualism and English-medium instruction. World Englishes, 30, 345-359.

Dudley-Evans T., \& St. John, M. J. (1998). Developments in ESP: A multi-disciplinary approach. Cambridge: Cambridge University Press.

Dunne, C. (2011). Developing an intercultural curriculum within the context of the internationalisation of higher education: Terminology, typologies and power. Higher Education Research \& Development, 30, 609-622.

Eurobarometer (2012). Retrieved from http://ec.europa.eu/public_opinion/archives/ebs/ebs_386_en.pdf

European Commission (2015). On the way to Erasmust. A statistical overview of the Erasmus programme in 2012-13. Luxembourg: Publications Office of the European Union. Retrieved from http://ec.europa.eu/dgs/education_culture/repository/education/library/publications/erasm us-stat-2012-13_en.pdf

Fortanet, I., \& Räisänen, Ch. (Eds.) (2008). ESP in European higher education. Integrating language and content. Amsterdam: John Benjamins. 
González, J., \& Wagenaar, R. (2003). Tuning educational structures in Europe. Bilbao: Universidad de Deusto. Retrieved from http://tuningacademy.org/wpcontent/uploads/2014/02/TuningEUI_Final-Report_SP.pdf

Greere, A., \& Räsänen, A. (2008). Year one report. LANQUA subproject on content and language integrated learning: Redefining 'CLIL'-Towards multilingual competence. Retrieved from https://www.unifg.it/sites/default/files/allegatiparagrafo/20-012014/lanqua_subproject_on_clil.pdf

Hyland, K. (2012). The past is the future with the lights on. Reflections on AELFE's 20th anniversary. Ibérica, 24, 29-42.

Knight, J. (2004). Internationalization remodeled: Definition, approaches and rationales. Journal of Studies in International Education, 8, 5-31.

Kuteeva, M., \& Airey, J. (2014). Disciplinary differences in the use of English in higher education. Reflections on recent policy developments. Higher Education, 67, 533-549.

Lasagabaster, D., Cots, J. M., Mancho-Barés, G. (2013). Teaching staff's views about the internationalisation of higher education: The case of two bilingual communities in Spain. Multilingual, 32(6), 751-778.

Leask, B. (2009). Using formal and informal curriculum to improve interactions between home and international students. Journal of Studies in International Education, 13, 205-221.

Leask, B. (2015). Internationalizing the curriculum. London: Routledge.

Mancho-Barés, G., \& Arnó-Macià, E. (2017). EMI lecturer training programmes and academic literacies: A critical insight from ESP. ESP Today, 5(2), 266-290. https://doi.org/10.18485/esptoday.2017.5.2.7

Mayhew, M. J., \& Grunwald, H. E. (2006). Factors contributing to faculty incorporation of diversity-related course content. The Journal of Higher Education, 77, 148-168.

McGrath, L., \& Kaufhold, K. (2016). English for specific purposes and academic literacies: Eclecticism in academic writing pedagogy. Teaching in Higher Education, 21, 933947. https://doi.org/10.1080/13562517.2016.1198762

Nilsson, B. (2003). Internationalisation at home from a Swedish perspective: The case of Malmö. Journal of Studies in International Education, 7, 27-40. https://doi.org/10.1177\%2F1028315302250178

Rosner, I. D., \& Christensen, J. (2016). Globalisation brought into the classroom: Reflections from the local context in social work and nursing education. Tiltai, 74(2), 21-32. http://dx.doi.org/10.15181/tbb.v74i2.1364

Sawir, E. (2011). Academic staff response to international students and internationalising the curriculum: The impact of disciplinary differences. International Journal for Academic Development, 16, 45-57.

Soria, K. M., \& Troisi, J. (2014). Internationalization at home alternatives to study abroad: Implications for students' development of global, international and intercultural competencies. Journal of Studies in International Education, 18, 261-280.

Swales, J. M. (1985). Episodes in ESP. A source and reference book on the development of English for science and technology. Oxford: Pergamon.

Swales, J. M., Barks, D., Ostermann, A. C., \& Simpson, R. C. (2001). Between critique and accommodation: Reflections on an EAP course for masters of architecture students. English for Specific Purposes, 20, 439-458.

Tange, H. (2010). Caught in the tower of Babel: University lecturers' experiences with internationalisation. Language and Intercultural Communication, 10, 137-149. 
Teekens, H. (2003). The requirement to develop specific skills for teaching in an intercultural setting. Journal of Studies in International Education, 7, 108-119.

Terraschke, A., \& Wahid, R. (2011). The impact of EAP study on the academic experiences of international post-graduate students in Australia. Journal of English for Academic Purposes, 10, 173-182.

Wächter, B., \& Maiworm, F. (Eds.) (2014). English-taught programmes in European higher education. Bonn: Lemmens.

ELISABET ARNÓ-MACIÀ is associate professor of English for Specific Purposes at Universitat Politècnica de Catalunya (Barcelona, Spain). Her research interests include technical and academic communication, the use of technology in languages for specific purposes, and internationalisation and multilingualism in higher education, in particular the implementation of English-Medium Instruction.

MARTA AGUILAR is associate professor of English for Specific Purposes at Universitat Politècnica de Catalunya (Barcelona, Spain). She is interested in academic and disciplinary discourses and in technical and academic writing for foreign language speakers. She has recently published on English-Medium Instruction and internationalisation in higher education. 